Preprint, the final version, of the article that has been transferred to the journal's production team.

To cite this article: Ginzarly, M., Farah, J., \& Teller, J. (2019). Claiming a role for controversies in the framing of local heritage values. Habitat International. Doi: 10.1016/j.habitatint.2019.05.001

\title{
Claiming a role for controversies in the framing of local heritage values
}

\begin{abstract}
This study focuses on the role of controversies in heritage management, considering more specifically cities characterized by tensions between community groups. In such cities, the regulatory and institutional systems are challenged by highly structured community-based initiatives and organizations. Using an analytical framework that assesses the regulatory system, urban conservation, and development practices, we compared two heritage management projects in Tripoli (Lebanon). Our results highlight the dichotomy between decision makers' and communities' approaches to the definition and management of heritage and to the struggle over the use of public spaces to reclaim heritage values. The discussion highlights how controversies emerge from the physical assets that are claimed as heritage, the range of values associated with tangible assets, and how local communities may coproduce heritage knowledge and actively contribute to the democratization of heritage values.
\end{abstract}

Keywords: cultural heritage, heritage management, urban governance, controversy, actors network, regulatory system, right to the city.

\section{Introduction}

At its core, heritage is politicized and contested along different axes: the temporal, the spatial, the cultural/economic, and the public/private (Avrami, Mason, \& de la Torre, 2000; Graham, Ashworth, \& Tunbridge, 2000; Smith, 2006). As Smith and Akagawa (2009) argued, controversy, conflict, and cultural/identity politics are inherent to heritage. The contested nature of heritage implies that even when heritage is largely framed by policies adopted at the national level, it is likely to be managed at the local level (Graham, 2002). At the international level, urban heritage management become more inclusive and participatory, as heritage concerns are integrated into urban planning and development practices (UNESCO, 2016). This change has been accompanied by a new set of criteria for heritage governance in which the role of the central state has shifted from that of a dominant actor to a regulator, a partner with many other stakeholders (civil society, the private sector, NGOs), and an enabler for public participation in the management of urban heritage (UNESCO, 2011). Nevertheless, in many countries, heritage governance is not yet regarded as a collaborative process between the state and the public. Lebanon is such a case in which the regulatory framework fails to legitimate and protect many aspects of the urban heritage, and the local community is alienated by the government's approach to urban development, as many heritage attributes are threatened by 
large private sector development projects (Davie, 2009; Hanna, 2010; Pietrostefani, 2014). Under such circumstances, the civil society starts to enforce its engagement in decision-making and heritage governance at the neighborhood and other local levels to protect their sense of community and identity. This results in a patchwork of multilevel actions and multiscale stakeholders with conflictual approaches to representation, conservation, development, and the politics of identity.

In Tripoli, Lebanon, there are three main arenas of heritage management - the national, local municipal, and civil society—which results in multiple simultaneous approaches to the governance of heritage, with networks of actors cooperating or opposing one another on different projects to serve their individual ends and interests. Such circumstances raise two relevant questions. First, in increasingly fragmented societies, what room is there for heritage management that recognizes the plurality of identities and mediates between different representations of history and urban experiences? Second, can controversies over heritage contribute to a more collaborative urban governance through the coproduction of local knowledge? We address these questions through a case study of urban development and conservation practices for two projects in Tripoli. We postulate that our case can be related to other cases in different contexts, which we illustrate throughout the text. We mobilize an integrated framework that incorporates themes from critical heritage studies that acknowledge the role of "nonexpert" actors, usually referred to as "locals", "residents", or "social activists", in shaping the dynamics of heritage production. Our framework further builds on ActorNetwork Theory (ANT) to address the interplay between social actors and the material settings of places in shaping urban controversies. In doing so, we maintain that the "dissonant", "conflictual", and "process-based" character of heritage values should be given greater attention in the sociopolitical framing of heritage management. We hereby consider that, far from being exclusively negative, controversies over urban redevelopment projects can be viewed as opportunities to build a deeper knowledge and further appropriation of local heritage values.

The purpose of this paper is to develop a deeper understanding of how the definition of heritage, its values, and limits can be negotiated and reframed among different actors. This paper is divided into four sections. We begin by developing the theoretical framework, drawing on critical conceptualization of the discursive and spatial nature of heritage. We incorporate anthropologically orientated critical heritage studies into conceptualizations of controversy analysis inspired by ANT (Callon \& Latour, 1981; Callon, 1984, 1998; Latour 2007; Jolivet \& 
Heiskenen, 2010; Venturini, 2010; Callon et al., 2011). Then, we present the methodology and related data for two projects. The next section presents the findings. First, we frame the discourses and practices of key actors through the assessment of two projects. Then, we draw on the main controversies resulting from the tension between the heritage by designation and heritage by appropriation and between communitarian and national identities. The last section presents some concluding remarks.

\section{Social activists and the dynamics of heritage production}

Since the early 1980s, the concept of heritage has been moving towards a value-based approach that addresses the city as a "living heritage" and incorporates associative values and multiple perspectives from different stakeholders (Poulios, 2014; Ginzarly et al., 2019). In parallel, scholars have developed multiple methods to address conflictual value systems within local cultural contexts (de la Torre \& Mason, 2002; Mason \& Avrami, 2002; Holden, 2006; Vita, Trillo, \& Perez, 2016; Heinich, 2017), and anthropologists have widely contributed to heritage studies in this regard. The most important themes in this literature are related to conflicts between "official" history and local historical knowledge, the contested representation of heritage between legitimate conceptions of the national identity and local identities related to everyday sociocultural constructs and experiences, the role of bureaucracies in daily life, and the struggle over citizenship rights and the right to the city (Herzfeld, 1991, 2006, 2016; Zhang, 2004). Given the conflictual character of heritage, scholars have advocated strongly for the involvement of all stakeholders in discussions about what to preserve and how to preserve it. Notions of "civic engagement", "participatory planning", and "inclusion" have come at the forefront of European and International declarations and recommendations for sustainable urban development and heritage conservation (UNESCO, 2016; UN-HABITAT, 2016; Beeksma \& De Cesari, 2018; Ginzarly et al., 2019). Nevertheless, some scholars argue that participatory planning is often manipulated, mediated by power, and conditioned by the constraints of the democratic character of the political sphere, which is influenced by market forces that set the "rules of the game". These scholars suggest that, at best, participatory planning leaves both sides disappointed (Getimis \& Kafkalas, 2002; Swyngedouw, 2005). Nevertheless, there are different types of participation, depending on the objectives for which participation is used, the scope of interaction between different actors, and the extent of citizen's power in determining the final decision (Arnstein, 1969; Lawrence, 2006). The various types of participation, mentioning the informative, consultative, functional, 
collaborative, and transformative result in different outcomes in terms of knowledge, decisionmaking, and power (Arnstein, 1969; Lawrence, 2006). Some scholars argue that participation remains associated with democratization and that participatory heritage practice depends upon the characteristics and negotiation processes of local contexts and that it is "articulated with shifting configurations of local governmentality" (Beeksma \& Cesari, 2018: 6). Thus, participation produces different effects and request a pre-determination about what types of participation are desirable and what effects are valued (McQuarrie, 2013).

Against this background, at the beginning of the 21st century, the ongoing debate about heritage value systems has provoked discussions about the "Authorised Heritage Discourse", "the global hierarchy of value", and "governmentality" (Herzfeld, 2004; Smith, 2006; De Cesari \& Herzfeld, 2015; De Cesari \& Dimova, 2018). Critical heritage studies have provided ethnographic inquiries on how social movements and local resistance tactics mobilize heritage to respond to official heritage narratives and to the hegemonic heritage discourse that excludes interpretative narratives from groups that are marginalised based on class, religion, race, or gender (De Cesari \& Herzfeld, 2015; Herzfeld, 2015). A number of scholars have examined the role of social movements in the transformation and management of conflict/post-conflict landscapes and the material processes that render them heritage sites (Hviding \& Rio, 2011; Jones et al., 2017; Demetriou \& Ilican, 2018). Discussions about how local production and practices of heritage build a sense of community and identity as a counterpart of officials' and experts' definitions of heritage have led to concepts such as history from below (Hall, 1999), multiculturalism (Samuel, 2012), heritage as social action (Byrne, 2007; Harrison, 2010), and heritage by appropriation (Rautenberg, 1998; Dupagne et al., 2005; Tweed \& Sutherland, 2007). Several pertinent case studies have been published. For instance, Mack (2017) showed how the clash between Syriac immigrants' interests and norms and Swedish integration and housing policies have produced an arena for the Syriac community to adapt and change the built environment into a space that reflects the identity of the community. Thus, at the intersection of top-down and bottom-up planning, users become planners (Mack, 2017). In a case study of Pasargadae in Iran, Jones et al. (2017) deeply investigated the strategic interactions of players and arenas in heritage contests to eventually claim a role for activists to incorporate Iran's pre-Islamic heritage within the official Islamic republic discourse and the popular understandings of national heritage. In a case study of the demolition of a historic neighborhood for new development in Kunming, China, Zhang (2006) showed how, despite stern state regulation, residents used several different tactics to fight for their right to the city, 
such as street protests, litigation through court, and the mobilization of the media. We hereby invite a consideration of the value of controversy and whether it can be regarded as a constructive common ground for discussions that contribute to decision-making. Critical thinking models have recognized the value of controversies as a means of keeping creative processes in urban spaces (Hutter, 2013), of raising alternatives narratives and pushing the boundaries of what is considered acceptable in the public sphere (Nguyen, 2018), and of formulating sustainable urban management practices (Skoglund \& Svensson, 2010).

These are just a few cases among many others that acknowledge the role of social actors and the spatial setting of places in moments of controversy over heritage. Within this framework, it is worth emphasizing that stakeholders' interests and values are themselves social constructs that are closely associated with the shifting identification, stabilization, and transformation of networks of agents, whether they are institutions, individuals, communities, or even built structures. To understand these processes, we rely here on the controversy analysis literature. This literature is marked by sciences and technologies studies and primarily by ANT (Marres \& Moats, 2015). In fact, according to ANT, the arena of objects, actors, and processes that emerge in the context of urban heritage conservation could be labeled an actor-network. Such an actor network is tied together by the "framing" (problématisation) of certain objects buildings and spaces - as "urban heritage" by certain actors. This framing is built on cognitive (values), institutional (laws), and economic (business models) dimensions, but it also relies on the very materiality of the objects and spaces that make the other dimensions possible. In this sense, the physical objects may become "actants" in a loose actor network brought together by the general framing, but also polarized around controversies (Callon, 1984, 1998; Latour, 2007). The cartography of these controversies allows us to transcend conventional sectorial, institutional and scalar levels of analysis and create a dynamic explanation of phenomena (Latour, 2007; Jolivet \& Heiskenen, 2010; Venturini, 2010; Callon et al, 2011).

\section{Data and methodology}

The two projects discussed in this paper are the Cultural Heritage and Urban Development Project (CHUD) and the Tall Parking Project in Tripoli, Lebanon. The first is located in the historic Mamluk core of the city and the second is in the Ottoman City Center at the periphery of the Mamluk core. A map of the project locations is presented in Figure 1. The first is part of a larger national project that addresses five historic cities in Lebanon and is funded by a loan

from the World Bank, the French Development Agency, and the Italian Agency for 
Development Cooperation. The second is a neighborhood and square scale project funded by the local government. Both projects sites are mixed-use living spaces that are characterized by built heritage assets. While the first project is nationally registered, the second project is not recognized as a heritage site even by local authorities. The Council of Development and Reconstruction (CDR) is the agency responsible for the implementation of both projects.

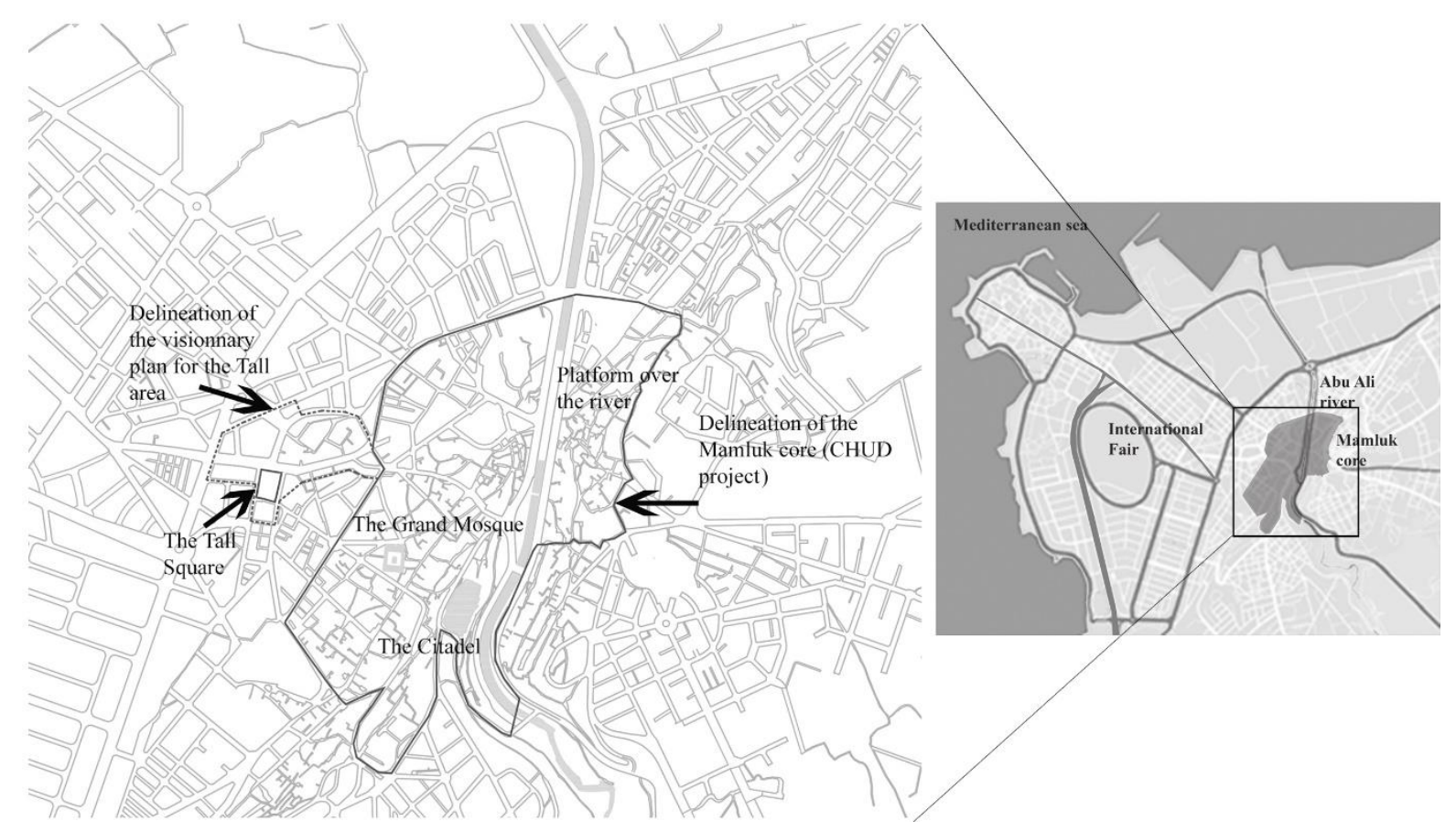

Figure 1: The location and delineation area of the two projects in Tripoli, Lebanon.

There are three types of data: documents, fieldwork in the two project areas, and interviews with key stakeholders. The documents include national and international conservation laws that are applicable to the study areas, project plans and proposals, brochures, videos, and other relevant items. The fieldwork included guided visits and walks in the two project areas with representatives of the municipality, the CDR, and civil society. The fieldwork examined interventions in the built environment that caused controversy and prompted heated debates about space and its use. The focus was on the spatial conditions of the project components such as the materials used, colors applied, architectural elements, the location (proximity and distance from certain attractions), and the proposed functions. The interviews focused on stakeholders with divergent interests who were involved in urban management, including representatives of community groups, representatives of civil society opposing the projects, decision makers, urban planners and designers, consultants, contractors, project managers, and administrators of Facebook groups that are concerned with urban 
heritage and development and conservation projects in the city. Twelve interviews were conducted for each project. The interview focused on seven issues: (1) the characteristics of the intervention areas, their delineation, and main resources; (2) the development of the projects over time; (3) actors involved; (4) projects objectives; (5) adopted tools and schemas; (6) the main pressures on local heritage assets; and (7) the successes and failures of the projects. Interviews were tape-recorded and then manually transcribed for extended qualitative analysis. The interviewers also took notes during the interviews to reflect on the ideas being discussed. Interviews lasted from 40 to 60 minutes. Six hours of transcription were needed for every 60 minutes of taped interview. We used an interpretive-descriptive analysis (see Tessier, 2012; Castleberry \& Nolen, 2018) to identify the context (where), the actors and their roles (who), the events and reaction to events (what), and processes/strategies (how).

\section{Two projects to analyze controversies in heritage management 4.1 CHUD Project}

The CHUD project was launched in Tripoli in 2001 with a project budget of approximately USD 20 million. The main objective of this ongoing project is to rehabilitate and protect the historic Mamluk core to enhance the local economy. Initially, the plan was to complete the project in five years. However, it is currently in phase two with one more phase to be fully implemented. The intervention strategies and decision-making for this project were restricted to certain actors, and there was controversy about whose heritage, what was included/excluded in the discourse about local identity, and the power relations between the different actors, including the international donors, the central government, and the local authority (the municipality). Experts from the World Bank developed the objectives, limits, and conditions for the project, and the consulting planning team from the CDR identified the action zones and interventions. The CDR is responsible for the execution of the project and is under the direct responsibility of the Lebanese national government. The Mayor and former members of the municipal council indicated during interviews that the municipality did not have an active role in decision-making; they were simply presented with the studies and project components. The delay in implementation of the project could be attributed in part to the absence of active involvement by a local institutional body that represents the city residents in the decisionmaking and implementation processes.

Moreover, the budget could only be invested in public properties, including buildings facades, streets, sidewalks, and gardens. This condition had an impact on the conservation discourse and related heritage values by focusing the discussion mainly on the mobilization of 
built heritage and its aesthetic beautification without considering the social, economic, and ecological values that could have been assessed through community engagement. As Silverman (2011) argued, tensions at the interfaces between local, national, and international levels lie at the core of contested cultural heritage, as decisions that are made at the international level unaware of local realities largely affect the local citizens, especially when their voices are not considered in decision-making (Smith \& Wobst, 2005). The CHUD is such a case, as the discussion about what is heritage and how to preserve it was mainly an institutionalized, expertbased dialogue that alienated the locals throughout the process and restricted heritage concerns to the Mamluk core, excluding the Ottoman, French colonial, and modern heritage assets. Such a restricted approach raises issues that are not only related to the age value of heritage, but also to concerns about identity, diversity, and inter-communal coexistence, as the Mamluk core is associated with the dominant Sunnite community in the city. Locals and the civil society claim that conservation practices should emerge from below to ensure durability and sustainability. They also believe that the CHUD project is an attempt to beautify from the outside what is damaged on the inside. Priority should not only be given to landmark monuments in their view, but also to infrastructure, renovation of residential buildings in bad condition, social development, and the alleviation of poverty.

The interviewees agreed that the main resources of the city are economic and cultural. The economic resources derive from the variety of souks (markets), including the gold, soap, woodcraft, copper, and perfume souks, and the cultural resources are associated with the city's historic assets. Nevertheless, depending on their interests and degree of involvement in the project, the interviewees had different expectations for the project. When interviewees were asked to delineate the project area and to talk about their expectations and the successes and failures of the project, they expressed different interests and heritage values. Figure 2 shows that only the urban planner and designer were conscious of the overall project area. To the planners, the project succeeded in spreading awareness about the importance of cultural heritage and in restoring the heritage character of the city and some of its monuments, such as Askar Khan, whereas shop owners were only aware of interventions near and around their shops. They did not appreciate the colors that were used, the quality of the materials and execution, and the delay in implementation because they felt that it is negatively affected their businesses. A representative of shop owners said that they still had yet to see any positive impact of this project on tourism or the economy. To municipal council members and social activists, the project was not an integrated one but the sum of punctual interventions. They claimed that the renovation practices in this project are cosmetic interventions that did not 
attempt to protect the architectural character, the monuments, or the intangible heritage of the city. They also thought that the restoration of the Askar Khan was not a complete success, as the building was not given a function and it was put under the supervision and management of the Ministry of Culture instead of the municipality. The multiple interests, uses, and consumption of heritage assets is a strong source of conflict between the various stakeholders involved (Graham et al., 2000). Interest groups that are able to organize collective action are better able to articulate project goals that reflect their own interests and to participate in decision-making (Lubell et al., 2006), whereas less powerful players' interests may be neglected. Eventually, the lack of balance between local interests and national and international goals limited the success of this project. 

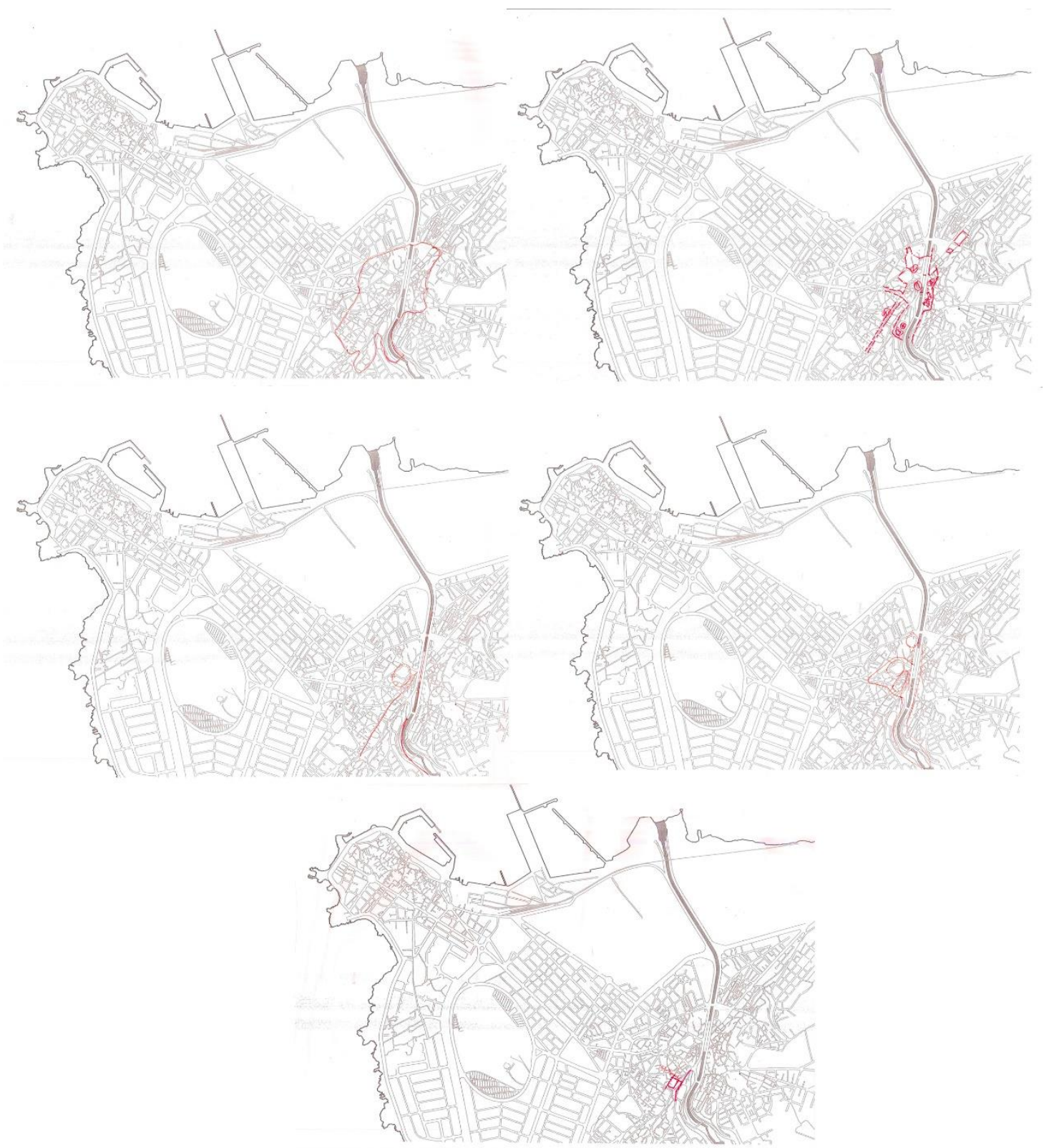

Figure 2: The different delineations of the project's area as illustrated by the different actors. Top left by the urban planner from the CDR-Top right by a former member of the municipal council- Middle left by a social activist- Middle right by a consultant- Bottom by a shop owner.

Some resistance was aimed mainly at contesting the uses proposed by the project's authors for the public spaces of the street. The shopkeepers' resistance took the form of microscale "tactical" opportunistic changes, and sometimes vandalism to the urban design interventions in the streetscape. Hence, the very materiality of the street became a considerable ally for those resisting the project (Aoun, 2007). Another controversial component of the project was the construction of a platform above the Abu Ali River, which crosses the Mamluk core. Shop owners, residents, and stakeholders strongly objected to the platform, and in the early phase of the project, activists conducted multiple resistance actions, which led to a long debate over the public space and identity representation. Again, the very materiality of the 
platform, especially its size, was a strong challenge for the project. In fact, despite it being very large, the platform was not big enough to host all of the street vendors who claimed the right to have kiosks on the platform, as envisioned in the project. Moreover, the function of the platform was continually negotiated among the different actors. Originally, the platform was supposed to host the vegetable kiosks, but the sellers did not respond to the planners' proposals and ended up selling clothing and shoes. In addition, according to the original plan, part of the platform was reserved for cultural events, but in the early phase of the project some locals used this area for parking, because the project had not provided a solution to the parking problem in the area. A few years later, this use was renegotiated and the locals asked for gathering points in the form of small café stalls (mainly for men). The municipality approved this demand and today this part of the platform is used for social interaction.

The Opponents of this project did not coordinate their efforts into a single, coherent actor network, aligned with a common framing (Callon, 1984). Instead, they worked individually or in small groups, they did not mobilize different networks, and their protests were mainly reactive, based on objections to marginal project proposals and applications, such as the difference between the brochures that were circulated before the project and images of the final project (Fig. 3). Some community members tried to take proactive steps to prevent the implementation of some of the project components, but they did not succeed. A former member of the municipal council said:

The donor agencies asked for public participation. I sent the World Bank by fax a petition signed by around a hundred shop-owners explaining our concerns. The next day I received a call from the CDR accusing me of delaying the project. They told me that if we keep [sic] complaining we will [sic] lose the funding and that we [sic] should accept the project as it is.

The opposition somehow failed to develop an alternative understanding of the place in order to coordinate a larger set of actors and interests. Thus, the controversy remained local and fragmented, even though the river and its uses have always played a structural role in the development and image of Tripoli as a whole (Ginzarly \& Teller, 2019). Quite paradoxically, the structural role of the river for the entire city may have worked against framing and mobilization efforts, as the river is typically regarded as a shared space, not a communitarian one, so this may have made it difficult to mobilize existing groups and networks for its conservation and enhancement. As mentioned previously, this project was entirely conducted by national experts and decision makers, without the municipality playing a role. Resistance should have been developed at the same level to have a real impact. As it was, the resistance 
remained mostly local and never involved national actor networks, such as political parties or communitarian organizations. Finally, international NGOs, such as ICOMOS and UNESCO, that could counterbalance the role of international donors typically concentrate their efforts on World Heritage Cities, leaving apart cities like Tripoli, which are not yet recognized as such. Nevertheless, the credibility of the World Heritage list has been questioned as "UNESCO's member states use the nomination process and promotion of world heritage sites for their own domestic agendas of cultural hegemony and state nationalism" (Askew, 2010: 23), and because inscription on the list is seen as biased in favor of cities that have the funding resources to pay consultants, prepare professional dossiers, and nominate sites (Meskell, 2018). Representation on the list is disproportionate, with $47.07 \%$ of World Heritage Sites located in Europe and North America, and only $8.7 \%$ in Africa, and $7.69 \%$ in Arab states (UNESCO, 2014). Moreover, heritage sites in Arab states receive attention based on the interest of the tourist industry and museums in the West (Karimi \& Rabbat, 2016). Accordingly, heritage sites that are not desirable tourist destinations do not receive much global attention.

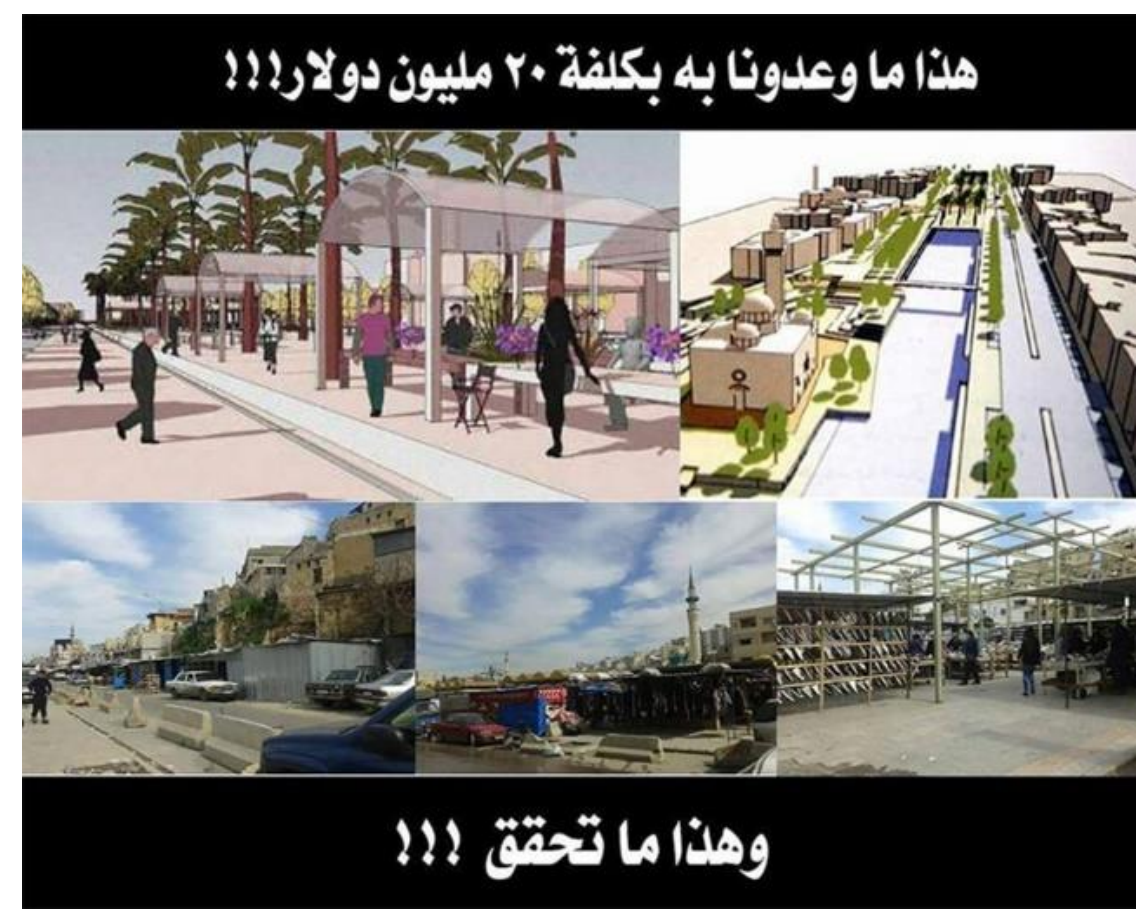

Figure 3: Source: Jalal Abas, 2016. The top two illustrations show the platform project proposal under the title "That's what they promised us at a cost of 20 million USD". The lower three illustrations show the platform after its construction under the title "and this what has been achieved". 


\subsection{Tall Project}

The Tall Square parking project was launched in 2014. The Lebanese government provided Tripoli with USD 19 million for development projects. In cooperation with the CDR, the municipality decided to invest part of this money in the construction of an underground parking facility, and the Ottoman Tall Square was selected to host four floors of underground parking (Fig. 4). In contrast to the first project, civil society was organized and worked in a collaborative way for a common cause on the Tall Square Project. It formed "The Engineering and Planning Team for the Development of Tripoli" and used social media ${ }^{1}$ as a way for engagement in heritage management and for developing an appropriate design for the public space. According to social activists, the square has historic and social value because it represents an important era in the city's history and provides a public space that brings different community groups together. In addition to conflict over conservation of the square as part of the city's heritage and common identity, the proposed design prompted a discussion about the spatiality, materiality, and everyday life of the public space. Opponents argued that the project would reduce public space in the square, destabilize the accessibility and openness of the public space, possibly impact the existing associations to everyday practices and uses of the space, and detract from the historic character of the area, as this Ottoman square is surrounded by many 18 th century structures and buildings. The engineering and planning team did not simply protest against the project, as in the CHUD project. They provided a study of the negative impacts of the project and developed an alternative proposal that could align and mobilize several interest groups. They also organized meetings with local political elites to discuss alternative solutions for traffic congestion and the need for parking lots. This example shows how a structured network empowered itself and moved from a passive receiver to an active contributor, engaging itself in decision-making to develop an alternative problematization of heritage, even though the place itself may be regarded as less significant than the Abu Ali River previously described. When the pressure increased, the Mayor asked a local urban designer to develop a visionary plan for the development of the Tall area and to include the parking as an integrated part of the project. This only intensified the debate, as locals saw it as an attempt to "parachute in" another project.

\footnotetext{
${ }^{1}$ Facebook group link: https://www.facebook.com/nomirab/
} 


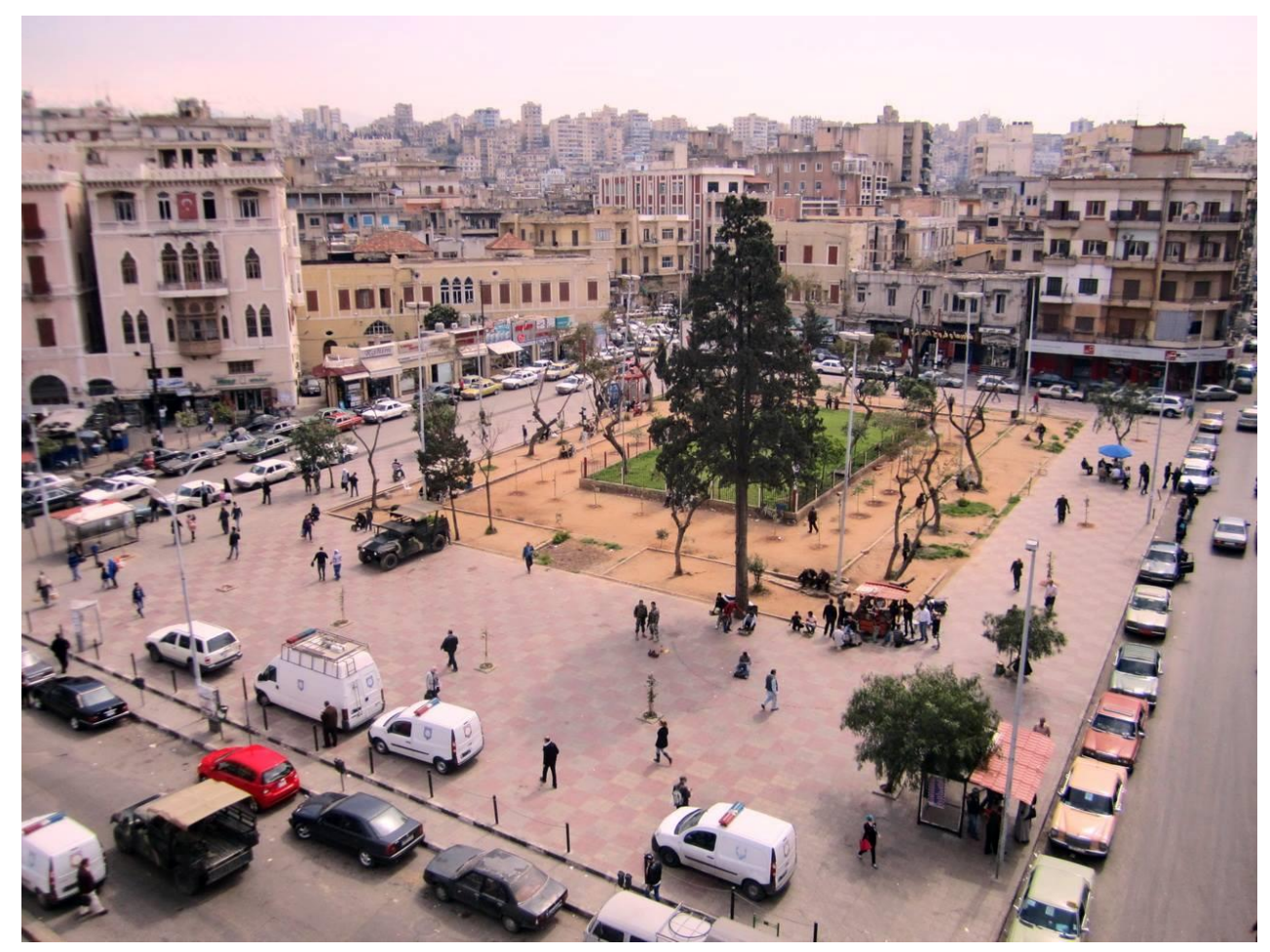

Figure 4: The Tall Square in Tripoli, Lebanon.

The activists started a Facebook group called "No to Tripoli Parking" to post their proposal, to spread awareness about the historical, social, and economic value of the Ottoman square, and to call for the democratization of heritage. They reminded the public of the CHUD failure, and called for protests against the Tall Square Project. This movement rapidly made headlines in local and national news outlets. The activists maintained pressure on the municipality and the politicians, and the project was finally stopped. The network had succeeded in shifting from a protest to a problem-framing role, especially by questioning the municipal plans for parking and mobility. They claimed that the municipality and the international experts had largely ignored the heritage value of the place. They provided local insights and knowledge about what heritage is and about how to preserve it to bridge the gap between conservation and development practices, thereby improving democracy and decisionmaking (Corburn, 2005). The network practice in this project contributed to the democratization and redefinition of heritage. This conception of heritage embodies cultural values associated with the living environment and everyday uses. In the following section, we frame the heritage discourse by addressing controversies that arise from the tension between heritage by appropriation and heritage by designation on one side, and communitarian and national identities on the other side. 


\section{The Main tensions of the two projects}

\subsection{Tension between communitarian and national identities}

The heritage conservation practices in Tripoli are continually reframed by the political interests of the actors in power on the Lebanese political scene, cultural and economic realities, and the changing approaches of different stakeholders towards national identity, modernity, and authenticity (Salem, 2011; Saliba, 2013). The resulting national narratives about identity and around centralized decision-making that ignores local daily practices and social production of space are a major source of conflict in heritage management. Nevertheless, the case of the Tall Square Project showed that resistance and protests by lobby groups can disrupt formal processes of heritage management, and that the tension between formal and unofficial understandings of heritage can create a space for change and innovation to eventually contribute to more collaborative urban governance. Today, two main categories of heritage coexist in Lebanese cities and they continually spark controversies in space and time over representativeness, identity, and memory. The first heritage category is related to the Lebanese national identity, whereas the second category is built upon communitarian identities that vary from the street scale through the neighborhood to the city scale. This communitarian identity seems to compete with the national identity, as locals see it as more representative of their city image and identity (Salem, 2011; Ginzarly \& Teller, 2018), because agreeing to a definition of a national heritage that could unite the fragmented Lebanese society has been unsuccessful (Sawalha, 2011; Puzon, 2017). As a result, local actors react by rescaling governance arenas from the national and city scales to the urban and neighborhood scales, to establish a collaborative arena at the city level that challenges established heritage discourses and practices.

In Tripoli, there are three main spheres of heritage management. At the national level, Islamic communitarian political parties have a strong presence in the city and they tend to refer to it as the "capital of the Sunnis", imposing a specific image of the city and raising controversies about local identity and the cultural values of heritage. The CHUD project, with its focus on the beautification of Islamic Mamluk heritage, can be seen as a prime example of such an image. At the municipal level, local notables with considerable political and economic capital express a duality regarding urban heritage that falls between heritage and modernity. They invest in large commercial development projects on one hand, and they defend the Tripolitan identity on the other hand. At the neighborhood level, strong localized social networks and neighborhood identity impact the city's governance. As argued by Seurat (1985), 
these neighborhoods have their own actors who defend their "identity" and fuel their "assabiyya". The definitions of local identity and heritage remain very complex, as they embed different meanings from the various actors who form alliances according to their different interests and apply diverse approaches to the heritage production process. As a result, different forms of appropriation and of claiming public space are articulated in the city. Claims over the public space can be seen in daily uses through the marking of the space (sidewalk, alley, etc.) with material objects (chairs, signs, etc.), or in the resistances to development proposals, such as the protesters who pitched tents and camped out on the Tall Square to claim their right to the public space (Fig. 5). As Kirshenblatt-Gimblett (1998: 7) argued, heritage is a "mode of cultural production in the present which has recourse to the past." When community groups mobilize heritage in terms of need/use values and social values that are shaped over time by informal and everyday practices and negotiations, they are contributing to the cultural production of locality to assert and challenge values imposed by the central state.
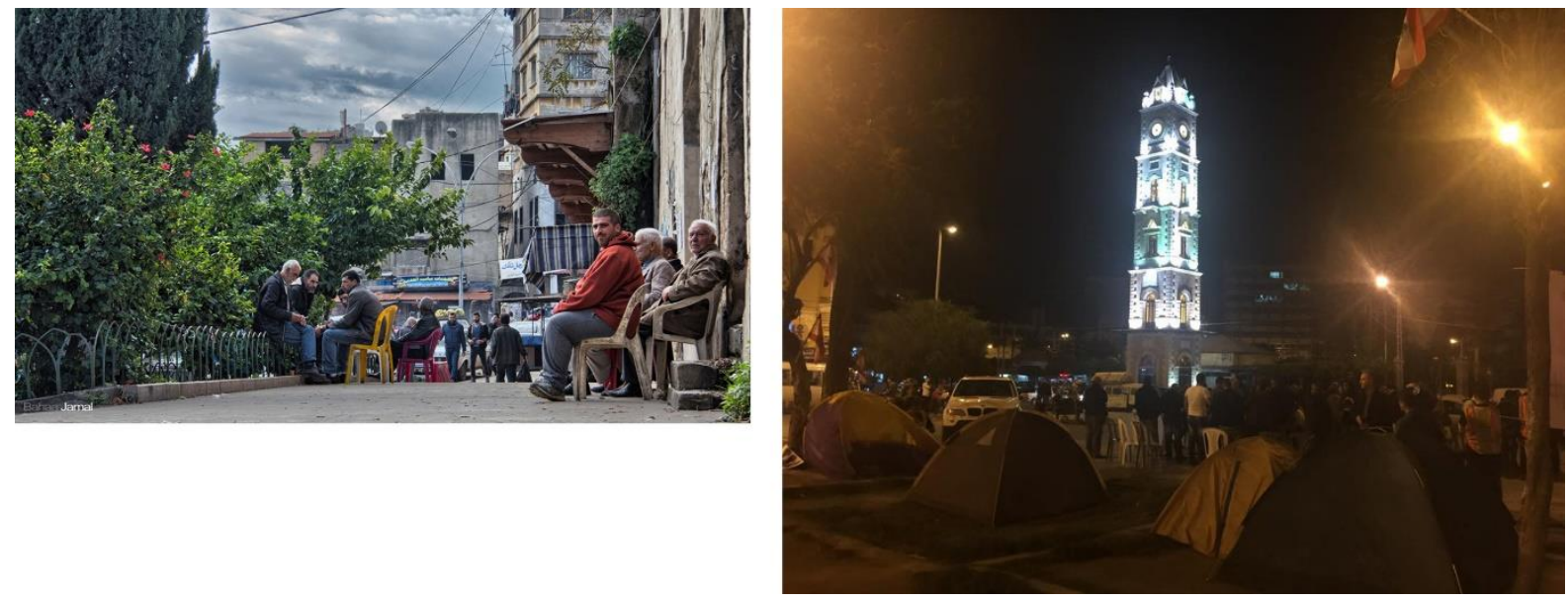

Figure 5: Left: Shows how men claim the streets. They put chairs out on the street to reserve their spot and gather. Right: shows the sit-in in the Tall Square and the claim of the public space.

5.2 Tension between heritage by designation and heritage by appropriation

Heritage management in Tripoli is a complex process that is filled with controversies among diverse actors and networks about the definition, limits, protection, and management of national identity and urban heritage. There is a tension between legal/designated heritage and the heritage by appropriation that emerges from public behavior and cultural expression. The Lebanese state mainly gives legitimacy to Medieval Mamluk built heritage, excluding a great share of the Ottoman legacy and French colonial heritage as part of the local identity and common history. The 1933 cultural heritage law that was drafted during the French mandate is 
still in force. This law is primarily concerned with the protection of archaeological findings, and only buildings that were built before the $19^{\text {th }}$ century are regarded as heritage. Since then, no law has been implemented to safeguard Lebanon's cultural heritage. Although a law project was penned in 2008, decrees for the operation and application of this law were never issued. At the operational level, the government has very restrictive policy for listing urban heritage. There are several reasons for the restrictive nature of this policy, including the persistent controversies about the value of some historical remains related to divergences between religious communities. Tripoli's historical past is physically represented in its Islamic Mamluk heritage. The more recent Ottoman, French, and modern heritage, even if it is not protected, remains an integral part of the city's landscape and identity. Both the CHUD and the Tall Square projects, somehow, represent a rejection of "colonial"/“Western"/“modern" heritage and attempt to forge an "Islamic/Arab" identity by solely celebrating Mamluk built artifacts. At the national level, the heritage discourse is largely intertwined with religious and political discourses because, in the Middle East, political decision makers conceive of the Islamic heritage in terms of political entities rather than as a cultural nexus (Gibb, 1971). Tripoli is not an isolated case with respect to sectarian concerns filtering decisions about what is worth saving. For example, Demetriou and Ilican (2018) argued that the dominant heritage discourse in Cyprus is characterized by a national political self-determination model that has encouraged the association of cultural heritage with specific ethno-national groups.

The lack of heritage designation increases the risk of demolition for some significant heritage assets. In fact, the destruction of heritage assets in Lebanon is a strategy and a means of political economy. This strategy has led to the demolition of many traditional buildings with historic heritage value. In another Lebanese city, Beirut, Puzon (2017) has shown that the loss of heritage assets remains fundamental in the cultural heritage paradigm. Tripoli has approximately 150 monuments on the list of the Directorate General of Antiquities (DGA). Some of these monuments are in poor condition and in danger of collapsing. Another 150 highly relevant buildings are not listed and remain under threat of demolition. Since the 1950s, after the flood of the Abu Ali River, Tripoli has witnessed the repeated destruction of built heritage as well as architectural and historical cultural values. First, the canalization of the river led to the demolition of around 2000 homes and Mamluk monuments (Nahas, 2001). In 1972, two Mamluk commercial streets, the coppersmith and shoe-maker markets, were demolished to make way for two major transportation arteries. More recently, the municipal government approved the demolition of many private properties that date back to the Ottoman and French 
colonial period to invest in profitable residential or institutional buildings. The demolition of Ottoman and French heritage assets cannot simply be attributed to real-estate development needs, because there also is a political dimension to heritage that asks the question, "what constitute worth saving" (Meskell, 2002: 565). In fact, the discussion about heritage demolition is especially relevant. Contemporary acts of heritage demolition and their impacts on local contexts and societies are widely discussed in relation to iconoclastic attitudes, cultural destruction, and memory erasure, as in many cases in the Middle East and North Africa (Stone \& Bajjaly, 2008; Sawalha, 2011; Quntar, 2013; Kalman, 2017), and they are discussed in relation to massive urban development projects in contexts such as China (Sofield \& Li, 1998; Silverman \& Blumenfield, 2013; Zhong \& Chen, 2017) or to punctual ones (Shipley \& Reyburn, 2003).

Our cases further emphasize that inadequate and obsolescent regulatory and institutional systems that are designed to protect heritage may put increasing pressure on those assets that are not legally listed. Profitable private developments are given priority over built heritage assets, and many embedded values of cultural heritage (social, economic, ecological) are not recognized or protected by the central state. Even though international organizations have highlighted the importance of these values in shaping local identities and the importance of their economic, social, and environmental impacts, these concepts have yet to be integrated into the national legislative framework. For instance, Lebanon ratified the 1983 UNESCO convention for the protection of cultural and natural heritage and the 2003 convention for the safeguarding of intangible heritage, but it still has not translated these conventions into national laws ${ }^{2}$. This outdated regulatory framework had impacts on both the CHUD and Tall Square projects. In the CHUD Project, there were no regulations in place to recognize the Abu Ali River as a cultural landscape and as a heritage asset that contributes to the city's identity and to people's collective memory. In the Tall Square Project, the regulatory framework did not acknowledge the cultural value of the Tall Square. In this context, local knowledge and activism are extremely important, as they are rooted in local culture, ecology, social contexts, and economies. Hence, controversies about heritage may contribute to the formulation of more sustainable urban development and management practices (Antweiler, 1998; World Bank,

\footnotetext{
2 In late 2017, the Parliament passed a new law for built heritage conservation that protects buildings in neighborhoods facing serious real-estate speculation by giving these buildings' owners "rights" to virtual additional construction surfaces. The owner can then sell these rights to developers in other more recently built neighborhoods. This law has created its own controversies that we will not discuss in this article, as it is too soon to assess the impacts of this recently passed law.
} 
1999; Corburn, 2005; Skoglund \& Svensson, 2010). Thus, the CHUD Project was a missed opportunity to coproduce knowledge about the sociocultural and ecological role of the river in the urban development of the city at large. Its heritage designation is inconsistent with local conceptions. A recent study showed that locals approach the history of their city as a continuous process that is reflected in old and contemporary developments and in the changes that have occurred in the city through time, with everyday experience being an essential part of people's cultural heritage and shared identity (Ginzarly \& Teller, 2018). As a result, the articulation of informal designation processes by lobbying groups starts at the local level. In Tripoli, social activists have launched a civil campaign to save the monuments and heritage of Tripoli and the Tripoli Antiquities Club to spread awareness about the importance of cultural heritage and common history and identity, and to advocate for the protection of cultural heritage assets. These movements did not influence the construction of the platform over the river, as that project is situated in a designated area and the state was not open to initiatives from below for internationally funded projects. In contrast, social activists succeeded in mobilizing different social actors in the Tall Square Project, which is still not designated as a heritage site. The fact that the Tall Square was not listed may have contributed to a more open-minded attitude by the authorities and strengthened the local political arena, whereas listing tends to transfer all decision-making to national bodies in Lebanon. Hence, listing appears to be a further impediment to local participation in such a configuration.

Today the campaign to save the monuments and heritage of Tripoli includes civil society organizations, intellectuals, academics, associations, and institutions working in the public sphere. It also has a heritage protection team of more than 150 volunteers. Through this campaign, activists work for their demands by initiating collaborations with public institutions, such as the municipality, the Ministry of Culture, and the Directorate General of Antiquities (DGA). For instance, the heritage protection team, in collaboration with the Committee of Antiquities and Heritage in the municipality, have documented and prepared detailed files about heritage buildings and sites in Tripoli beyond the boundaries of the Mamluk core. The list was submitted to the DGA with a demand for national listing to ensure the protection of these heritage assets and for revision of existing historic core delineation. Because of the cost associated with such listings, the campaign has not yet achieved its demands. This discussion about campaigns and organizations initiated by local experts and practitioners to provide alternative approaches to official urban management scenarios, and to suggest a reconceptualization of heritage that acknowledges the city's social and contemporary urban 
fabric resonates with Panetta's (2018) work on the practices of an independent urban research group with respect to "heritage making" and the provision of "alternative practice" to urban development and conservation in Downtown Cairo. The attitude discussed in this section highlights the development of a form of heritage production that turns resistance to heritage by designation into a movement for knowledge production related to heritage values and conservation (Wang, 2013).

\section{Conclusion: The Contributions of Controversy}

In this paper, we discussed controversies in the value paradigms of stakeholders involved in heritage management. We applied an analytical framework that addresses the involvement of civil society in mobilizing heritage to protest against urban conservation and development practices that are seen to negatively impact the built and sociocultural assets of the landscape. The various stakeholders approached the projects' weaknesses and strengths differently based on their own interests and value systems. Therefore, they had different expectations, which led to controversies over heritage. These controversies prompted governance initiatives from civil society actors that contributed to a rescaling of governance arenas to introduce a collaborative arena at the local and community levels. The new arena promotes a logic of governance that elicits local knowledge and builds on democratic representativeness. In this context, controversies become an opportunity to coproduce local knowledge about heritage and to contribute to improved urban management.

The efforts of the activists to update and revise existing national heritage listing is an attempt to extend the limits of heritage. They acknowledge colonial and modern heritage assets to reflect on the historicity of the city and its change over time, and to go beyond the definition of the historic center as the sole representative of the city's cultural heritage. For the locals, the aesthetic value of historic assets is less important than the socioeconomic values related to daily life. The discussion about the role of local knowledge, daily practices, and socio-cultural processes that contribute to the identity of the city is much broader than what we have examined in this study. Practices and spaces where heritage boundaries are challenged and alternatives to dominant national narratives are articulated should be given greater consideration by experts and decision makers, not as a counterpart to the official heritage discourse, but as a complementary component that helps to represent diversity and multiculturalism and provides an arena that tackles heritage controversies and balances various interests. The current discussion about heritage has moved from a focus on conservation to address the management 
of change. As the reciprocal relationship between ecological processes and the urban environment leads to a constantly changing urban landscape, cultural values and attributes change accordingly. Thus, urban management and planning tools should be applied to maintain continuity and manage change.

One of the things we have shown in this study is that the involvement of international donors and agencies complicates discussions about which heritage attributes should be preserved or developed, as well as whose cultural identity and social, economic, political, ecological, and historical values should be used to make those decisions. The CHUD case indicates that at the interface of international, national, and local concerns, the latter seem to be the weakest link. The capacity of local activists to influence decisions that come from a macro international level remains questionable. This is quite paradoxical, as international organizations such as UNESCO and the World Bank have called for community empowerment, but in cities in the Global South, the procedural and discursive aspects of participation remain critical. It remains for future studies to illustrate how internationally funded and supervised projects can add a layer of complexity from a conflict management perspective.

Finally, we acknowledge the role that social media played in empowering the local community. Social media helped to materialize and foster public engagement in the Tall Square Project because the community was active online and offline (in the field). Eventually, the public achieved its goal. Such successful activism sheds light on the role that social media can play in the redefining the limits of heritage areas and categories and in allowing inclusiveness in the cultural heritage realm. 


\section{References}

Antweiler, C. (1998). Local Knowledge and Local Knowing. An Anthropological Analysis of Contested "Cultural Products" in the Context of Development." Anthropos, 93(4/6), 469-494. https://www.jstor.org/stable/40464844

Arnstein, S. R. (1969). A Ladder Of Citizen Participation. Journal of the American Institute of Planners, 35(4), 216-224. https://doi.org/10.1080/01944366908977225

Aoun, O. (2007). Les procédés participatifs dans le projet CHUD à Tripoli: la crise de légitimation de l'action urbaine entre procédés participatifs de la Banque Mondiale et culture locale. Masters Thesis in urban planning, Lebanese University

Askew, M. (2010). The magic list of global status: UNESCO, world heritage and the agendas of states. In S. Labadi \& C. Long (Eds.), Heritage and globalisation (pp. 19-44). Abingdon: Routledge.

Avrami, E., Mason, R., \& de la Torre, M. (2000). Values and Heritage Conservation: Research Report. Los Angeles: The Getty Conservation Institute. Retrieved from http://www.getty.edu/conservation/publications_resources/pdf_publications/pdf/valuesrpt.pdf

Beeksma, A., \& De Cesari, C. (2018). Participatory heritage in a gentrifying neighbourhood: Amsterdam's Van Eesteren Museum as affective space of negotiations. International Journal of Heritage Studies, O(0), 1-18. https://doi.org/10.1080/13527258.2018.1509230

Byrne, D. R. (2007). Heritage as social action. In G. Fairclough, R. Harrison, J. Schofield, \& J. J. H. Jameson (Eds.), The Heritage Reader (1 edition, pp. 149-173). New York: Routledge.

Callon, M., \& Latour, B. (1981). Unscrewing the Big Leviathan; or How Actors Macrostructure Reality, and How Sociologists Help Them To Do So? In K. KnorrCetina \& A. V. Cicourel (Eds.), Advances in Social Theory and Methodology: Toward an Integration of Micro- and MacroSociologies (pp. 277-303). http://www.bruno-latour.fr/node/388

Callon, M. (1984). Some elements of a sociology of translation: domestication of the scallops and the fishermen of St Brieuc Bay. The Sociological Review, 32, 196-233. https://doi.org/10.1111/j.1467954X.1984.tb00113.x

Callon, M., Lascoumes, P., Barthe, Y., \& Burchell, G. (2011). Acting in an uncertain world: an essay on technical democracy (1. paperback ed). Cambridge: MIT Press.

Castleberry, A., \& Nolen, A. (2018). Thematic analysis of qualitative research data: Is it as easy as it sounds? Currents in Pharmacy Teaching and Learning, 10(6), 807-815.

https://doi.org/10.1016/j.cptl.2018.03.019

Corburn, J. (2005). Street Science: Community Knowledge and Environmental Health Justice (1 edition). Cambridge, MA: The MIT Press.

Davie, M. (2009). La construction nationale et l'héritage Ottoman au Liban. In Patrimoines culturels en Méditerranée orientale: recherche scientifique et enjeux identitaires (J.-C. DAVID and S. MÜLLER CELKA, p. 3ème atelier (26 novembre 2009): Les héritiers de l'Empire ottoman et l'héritage refusé). Rencontres scientifiques en ligne de la Maison de l'Orient et de la Méditerranée. Lyon: Maison de l’Orient et de la Méditerranée.

De Cesari, C., \& Herzfeld, M. (2015). Urban Heritage and Social Movements. In L. Meskell (Ed.), Global heritage: a reader (Vol. 12, pp. 171-195). Chichester: Wiley Blackwell. Retrieved from https://dare.uva.nl/search?identifier=c988e7b0-4bb5-42e7-b2c5-a949c41e82ff

De Cesari, C., \& Dimova, R. (2018). Heritage, gentrification, participation: remaking urban landscapes in the name of culture and historic preservation. International Journal of Heritage Studies, $O(0), 1-7$. https://doi.org/10.1080/13527258.2018.1512515 
de la Torre, M., \& Mason, R. (2002). Introduction In Assessing the Values of Cultural Heritage. (Research) (pp. 3-4). Los Angeles: The Getty Conservation Institute. Retrieved from https://www.getty.edu/conservation/publications_resources/pdf_publications/pdf/assessing.pdf

Demetriou, O., \& Ilican, M. E. (2018). A peace of bricks and mortar: thinking ceasefire landscapes with Gramsci. International Journal of Heritage Studies, 0(0), 1-17.

https://doi.org/10.1080/13527258.2017.1413673

Dupagne, A., Ruelle, C., \& Teller, J. (2005). Sustainable Development of Urban Historical Areas Through an Active Integration Within Towns (No. Research Report no. 16,).

http://www.lema.ulg.ac.be/downloads/Suit.pdf

Fibiger, T. (2015). Heritage erasure and heritage transformation: how heritage is created by destruction in Bahrain. International Journal of Heritage Studies, 21(4), 390-404.

https://doi.org/10.1080/13527258.2014.930064

Getimis, P., \& Kafkalas, G. (2002). Empirical Evidence and Comparative Analysis of Policy-Making in the Pursuit of Innovation and Sustainability. In H. Heinelt, P. Getimis, G. Kafkalas, R. Smith, \& E. Swyngedouw (Eds.), Participatory Governance in Multi-Level Context: Concepts and Experience (pp. 155-171). https://doi.org/10.1007/978-3-663-11005-7_8

Gibb, H. A. R. (1971). The Heritage of Islam in the Modern World (III). International Journal of Middle East Studies, 2(2), 129-147. https://www.jstor.org/stable/162259

Ginzarly, M., \& Teller, J. (2018). Eliciting cultural heritage values: landscape preferences vs representative images of the city. Journal of Cultural Heritage Management and Sustainable Development, 8(3), 257-275. https://doi.org/10.1108/JCHMSD-06-2017-0031

Ginzarly, M., Houbart, C., \& Teller, J. (2019). The Historic Urban Landscape approach to urban management: a systematic review. International Journal of Heritage Studies, 1-21. https://doi.org/10.1080/13527258.2018.1552615

Ginzarly, M., \& Teller, J. (2019). Operationalizing the HUL Recommendation in Urban River Corridors: Challenges and Perspectives. In A. Pereira Roders \& F. Bandarin (Eds.), Reshaping Urban Conservation (Vol. 2, pp. 511-527). Singapore: Springer Singapore. https://doi.org/10.1007/978-98110-8887-2_29

Graham, B., Ashworth, G. J., \& Tunbridge, J. E. (2000). A Geography of Heritage: Power, Culture and Economy. Arnold.

Graham, B. (2002). Heritage as Knowledge: Capital or Culture? Urban Studies, 39(5-6), 1003-1017. https://doi.org/10.1080/00420980220128426

Hall, S. (1999). Un-settling 'the heritage', re-imagining the post-nationWhose heritage? Third Text, 13(49), 3-13. https://doi.org/10.1080/09528829908576818

Hanna, M. (2010). L'Echec des politiques patrimoniales au Liban: Acteurs et Enjeux. Laboratoire Espace Nature et Cultures ENEC, Paris IV.

Harrison, R. (2010). Heritage as Social Action. In S. West (Ed.), Understanding heritage in practice (pp. 240-276). Manchester: Manchester University Press.

Heinich, N. (2017). Des valeurs : Une approche sociologique (Vol. 34/2). Paris: Editions Gallimard.

Herzfeld, M. (1991). A place in history: social and monumental time in a Cretan town. Princeton, N.J: Princeton University Press.

Herzfeld, M. (2004). The Body Impolitic: Artisans and Artifice in the Global Hierarchy of Value. University of Chicago Press. 
Herzfeld, M. (2006). Spatial Cleansing: Monumental Vacuity and the Idea of the West. Journal of Material Culture, 11(1-2), 127-149. https://doi.org/10.1177/1359183506063016

Herzfeld, M. (2015). Heritage and the Right to the City: When Securing the Past Creates Insecurity in the Present. Heritage \& Society, 8(1), 3-23. https://doi.org/10.1179/2159032X15Z.00000000035

Herzfeld, M. (2016). Siege of the Spirits: Community and Polity in Bangkok. Chicago: University of Chicago Press. Retrieved from http://doi.wiley.com/10.1111/amet.12620

Holden, J. (2006). Cultural value and the crisis of legitimacy why culture needs a democratic mandate. London: Demos.

Hutter, M. (2013). Controversies about and in creative cities. In D. Wiktor-Mach \& P. Radwański (Eds.), The idea of creative city: The urban policy debate (pp. 5-10). The WZB Berlin Social Science Center: European Scientific Institute, ESI. Retrieved from

https://blogs.city.ac.uk/cci/2014/10/26/controversies-and-contradictions-around-creativity-in-cities/

Hviding, E., \& Rio, K. M. (Eds.). (2011). Made in Oceania: Social Movements, Cultural Heritage and the State in the Pacific. Wantage England: Sean Kingston Publishing.

Jolivet, E., \& Heiskanen, E. (2010). Blowing against the wind - An exploratory application of actor network theory to the analysis of local controversies and participation processes in wind energy. ENERGY POLICY, 38(11), 6746-6754.

Jones, T., Mozaffari, A., \& Jasper, J. M. (2017). Heritage Contests: What Can We Learn from Social Movements? Heritage \& Society, 10(1), 1-25. https://doi.org/10.1080/2159032X.2018.1428445

Kalman, H. (2017). Destruction, mitigation, and reconciliation of cultural heritage. International Journal of Heritage Studies, 23(6), 538-555. https://doi.org/10.1080/13527258.2017.1289475

Kirshenblatt-Gimblett, B. (1998). Destination culture: tourism, museums, and heritage. Berkeley: University of California Press.

Latour, B. (2007). Reassembling the Social: An Introduction to Actor-Network-Theory. Oxford, New York: Oxford University Press.

Lawrence, A. (2006). 'No Personal Motive?' Volunteers, Biodiversity, and the False Dichotomies of Participation. Ethics, Place \& Environment, 9(3), 279-298.

https://doi.org/10.1080/13668790600893319

Lubell, M., Vedlitz, A., Zahran, S., \& Alston, L. T. (2006). Collective Action, Environmental Activism, and Air Quality Policy. Political Research Quarterly, 59(1), 149-160.

https://doi.org/10.1177/106591290605900113

Mack, J. (2017). The construction of equality: Syriac immigration and the Swedish city. Minneapolis: University of Minnesota Press.

Marres, N., \& Moats, D. (2015). Mapping Controversies with Social Media: The Case for Symmetry. Social Media + Society, 1(2), 2056305115604176.

https://doi.org/10.1177/2056305115604176

Mason, R., \& Avrami, E. (2002). Heritage values and challenges of conservation planning. In Management Planning for Archaeological Sites: An International Workshop Organized by the Getty Conservation Institute and Loyola Marymount University, 19-22 May 2000, Corinth, Greece. Getty Publications.

McQuarrie, M. (2013). No Contest: Participatory Technologies and the Transformation of Urban Authority. Public Culture, 25(1), 143-175. https://doi.org/10.1215/08992363-1890495

Meskell, L. (2002). The Intersections of Identity and Politics in Archaeology. Annual Review of Anthropology, 31(1), 279-301. https://doi.org/10.1146/annurev.anthro.31.040402.085457 
Meskell, L. (2018). A Future in Ruins: UNESCO, World Heritage, and the Dream of Peace. Oxford, New York: Oxford University Press.

Nahas, C. (2001). Stakeholder Analysis and Social Assessment for the Proposed Cultural Heritage and Tourism Development Project (pp. 64-106). Beirut, Lebanon: CDR \& Information International. Retrieved from

http://charbelnahas.org/textes/Amenagement_et_urbanisme/Cultural_Heritage_Report/E-Tripoli_64106.pdf

Nguyen, T. (2018). Queering Australian Museums: Management, Collections, Exhibitions, and Connections (A thesis submitted in fulfilment of the requirements for the degree of Doctor of Philosophy). Museum Studies, Faculty of Arts and Social Sciences. The University of Sydney, Sydney, Australia.

Karimi, P., \& Rabbat, N. (2016, December 12). The Demise and Afterlife of Artifacts. Retrieved January 28, 2019, from http://we-aggregate.org/piece/the-demise-and-afterlife-of-artifacts

Panetta, C. (2018). An 'alternative framework for development:' state-citizen relations, urban revitalization, and Downtown Cairo's passageways. International Journal of Heritage Studies, O(0), 1-17. https://doi.org/10.1080/13527258.2018.1493703

Pietrostefani, E. (2014). Valuating urban heritage in a development perspective: The roles of designation and appropriation for heritage policy design in Lebanon (Master's thesis in International Development). Paris School of International Affairs, France.

Poulios, I. (2014). Past in the Present: a Living Heritage Approach - Meteora, Greece. London: Ubiquity Press Ltd.

Puzon, K. (2017). Saving Beirut: heritage and the city. International Journal of Heritage Studies, O(0), 1-12. https://doi.org/10.1080/13527258.2017.1413672

Quntar, S. A. (2013). Syrian Cultural Property in the Crossfire:: Reality and Effectiveness of Protection Efforts. Journal of Eastern Mediterranean Archaeology \& Heritage Studies, 1(4), 348351. https://doi.org/10.5325/jeasmedarcherstu.1.4.0348

Rautenberg, M. (1998). L'emergence patrimoniale de l'ethnologie entrem'emoire et politiques publiques. In D. Poulot (Ed.), Patrimoine et modernité (pp. 279-291). Paris: L'Harmatan.

Salem, G. (2011). Les enjeux du patrimoine au liban. Baalbek: quelles échelles pour quels patrimoines (PhD Thesis in Geography and Urban Planning). Lyon University.

Saliba, R. (2013). Historicizing Early Modernity — Decolonizing Heritage: Conservation Design Strategies in Postwar Beirut. Traditional Dwellings and Settlements Review, 25(1), 7-24. https://www.jstor.org/stable/23612198

Samuel, R. (2012). Theatres of Memory: Past and Present in Contemporary Culture. Verso Books.

Seurat, M. (1985). Le quartier de Bâb Tebbâné à Tripoli (Liban): étude d'une 'asabiyya urbaine. In CERMOC (Ed.) Mouvements communautaires et espaces urbains au Machreq. Beirut: CERMOC.

Sawalha, A. (2011). Reconstructing Beirut: memory and space in a postwar Arab city. Austin, Tex.; Chesham: University of Texas Press ; Combined Academic [distributor.

Shipley, R., \& Reyburn, K. (2003). Lost Heritage: a survey of historic building demolitions in Ontario, Canada. International Journal of Heritage Studies, 9(2), 151-168. https://doi.org/10.1080/1352725032000085278

Silverman, H. (2011). Contested Cultural Heritage: A Selective Historiography. In Contested Cultural Heritage (pp. 1-49). https://doi.org/10.1007/978-1-4419-7305-4_1 
Silverman, H., \& Blumenfield, T. (2013). Cultural Heritage Politics in China: An Introduction. In T. Blumenfield \& H. Silverman (Eds.), Cultural Heritage Politics in China (pp. 3-22). New York, NY: Springer New York. https://doi.org/10.1007/978-1-4614-6874-5_1

Smith, L. (2006). Uses of Heritage. Routledge.

Skoglund, P., \& Svensson, E. (2010). Discourses of Nature Conservation and Heritage Management in the Past, Present and Future: Discussing Heritage and Sustainable Development from Swedish Experiences. European Journal of Archaeology, 13(3), 368-385. https://doi.org/10.1177/1461957110386703

Smith, C., \& Wobst, H. M. (Eds.). (2005). Decolonizing theory and practice. In Indigenous archaeologies: decolonizing theory and practice (pp. 1-16). London; New York: Routledge.

Smith L., Uses of heritage, 2006, Routledge.

Smith, L., \& Akagawa, N. (2009). Introduction. In L. Smith \& N. Akagawa (Eds.), Intangible heritage (pp. 1-9). London; New York: Routledge.

Sofield, T. H. B., \& Li, F. M. S. (1998). Tourism development and cultural policies in China. Annals of Tourism Research, 25(2), 362-392. https://doi.org/10.1016/S0160-7383(97)00092-3

Stone, P. G., \& Bajjaly, J. F. (2008). The Destruction of Cultural Heritage in Iraq. Boydell \& Brewer Ltd.

Swyngedouw, E. (2005). Governance Innovation and the Citizen: The Janus Face of Governancebeyond-the-State. Urban Studies, 42(11), 1991-2006. https://doi.org/10.1080/00420980500279869

Tessier, S. (2012). From Field Notes, to Transcripts, to Tape Recordings: Evolution or Combination? International Journal of Qualitative Methods, 11(4), 446-460.

https://doi.org/10.1177/160940691201100410

Tweed, C., \& Sutherland, M. (2007). Built cultural heritage and sustainable urban development. Landscape and Urban Planning, 83(1), 62-69. https://doi.org/10.1016/j.landurbplan.2007.05.008

UNESCO. (2011). Recommendation on The Historic Urban Landscape. UNESCO World Heritage Center: Paris, France. Retrieved from http://www.stellenboschheritage.co.za/wpcontent/uploads/UNESCO-Historic-Urban-Landscapes-Recommendation-Short-Nov2011.pdf

UNESCO. (2014). UNESCO World Heritage Centre - World Heritage List. Retrieved February 3, 2019, from UNESCO World Heritage Centre website: https://whc.unesco.org/en/list/

UNESCO. (2016). The Historic Urban Landscape Guidebook: Managing heritage in dynamic and constantly changing urban environments. Retrieved from http://www.hulballarat.org.au/resources/HUL\%20Guidebook_2016_FINALWEB.pdf

UN-HABITAT. (2016). The New Urban Agenda. Retrieved February 6, 2019, from http://habitat3.org/the-new-urban-agenda/

Venturini, T. (2010). Diving in magma: how to explore controversies with actor-network theory. Public Understanding of Science, 19(3), 258-273. https://doi.org/10.1177/0963662509102694

Vita, G. E. D., Trillo, C., \& Perez, A. M.-. (2016). Community planning and urban design in contested places. Some insights from Belfast. Journal of Urban Design, 21(3), 320-334.

https://doi.org/10.1080/13574809.2016.1167586

Wang, C. (2013). Heritage formation and cultural governance: the production of Bopiliao Historic District, Taipei. International Journal of Heritage Studies, 19(7), 676-691. https://doi.org/10.1080/13527258.2012.687696 
World Bank. (1999). World Development Report 1998/1999: Knowledge for Development. New York: Oxford University Press. Retrieved from

https://openknowledge.worldbank.org/handle/10986/598

Zhang, L. (2004). Forced From Home: Property Rights, Civic Activism, And The Politics Of Relocation In China. Urban Anthropology and Studies of Cultural Systems and World Economic Development, 33(2/4), 247-281.

Zhang, L. (2006). Contesting Spatial Modernity in Late-Socialist China. Current Anthropology, 47(3), 461-484. https://doi.org/10.1086/503063

Zhong, X., \& Chen, X. (2017). Demolition, rehabilitation, and conservation: heritage in Shanghai's urban regeneration, 1990-2015. Journal of Architecture and Urbanism, 41(2), 82-91.

https://doi.org/10.3846/20297955.2017.1294120 